\title{
Variation of larval fish distributions associated with variability in the location of a shelf-slope front
}

\author{
Ana Sabatés*, M. Pilar Olivar \\ Instituto de Ciencias del Mar, CSIC, Paseo Joan de Borbó, s/n, E-08039 Barcelona, Spain
}

\begin{abstract}
This study examines the extent of the interaction between the short-time-scale variability in the location of the shelf-slope salinity front and the species composition and abundance of larval fish in the NW Mediterranean. Three extensive cruises were carried out during spring (May and June 1992), a season characterized by high mesoscale variability. Variations in the position of the shelf-slope front were correlated with large changes in the distribution and abundance of fish larvae. In the 3 surveys, offshore dispersal of fish larvae of shelf-dwelling species appeared to be limited by the geographical position of the front. When the frontal structure was detected over the shelf, the distribution of larvae of shelf-dwelling species was confined to the coastal side of the front, while larvae of mesopelagic fish species were located on the oceanic side. When the front was detected over the slope, it did not act as a barrier separating the larval distributions of shelf and oceanic species but instead limited the offshore extent of the larval distribution of shelf species.
\end{abstract}

KEY WORDS: Physical-biological coupling Shelf-slope front Fish larvae NW Mediterranean

\section{INTRODUCTION}

Mesoscale physical processes play a major role in determining the patterns of abundance and distribution of larval fish populations. Structures such as eddies and density fronts may act as mechanisms for confinement and concentration, thereby contributing to an increase in mesoscale spatial heterogeneity (Kiørboe et al. 1988, Govoni et al. 1989, Kingsford 1990, Grimes \& Finucane 1991). Many researchers consider that there is a cause-and-effect relationship between physical factors and the distribution of organisms and have assumed hydrodynamics to be the force driving the dynamics of aquatic ecosystems (Legendre \& Demers 1984). While associations between the spatial distribution patterns observed for physical and biological parameters may suggest an interaction between the two, reliable verification of the existence of biological-physical interactions and coupling requires that these associations occur repeatedly over time. Horizontal distribution patterns of plankton are

•E-mail: anas@icm.csic.es also affected by biological processes, but biologicalphysical interactions are considered to be more important than purely biological forcing mechanisms (Mackas et al. 1985).

The permanent shelf-slope front is the dominant oceanographic feature off the Catalan coast (Northwestern Mediterranean Sea) (Font et al. 1988). Essentially, it is a salinity front separating low salinity shelf water from the more saline offshore water. The front intersects the seabed at depths of nearly $300 \mathrm{~m}$ and is usually observed at the surface near the $1000 \mathrm{~m}$ isobath (Garcia et al. 1994). The frontal structure is associated with a current running in a southwesterly direction, just inshore of the front, at speeds of 20 to $30 \mathrm{~cm}$ $\mathrm{s}^{-1}$. Previous ichthyoplankton studies off the Catalan coast showed that the topography and hydrographic features greatly influenced larval distribution. An observed gradual increase of larval concentrations across the continental shelf, with maximum values over the edqe, sugqested a positive influence of the front on this general pattern (Sabatés 1990a). Those investigations, however, were focused on the shelf, and did not cover the frontal region. Therefore, in 
order to test this hypothesis, both sides of the front were sampled in the present study.

The system formed by the shelf-slope front and the associated current show instability (Wang et al. 1988), particularly in spring, a season of high mesoscale variability associated with inputs of fresh water, chiefly from the Rhône River (Masó \& Tintoré 1991). It has been noted that the presence of these continental waters over the shelf may rapidly change the hydrodynamic conditions, significantly altering the structure of fish larval populations. Some of these alterations have already been studied (Sabatés 1990b, Sabatés \& Masó 1992). The goal of the present study was to establish the extent of interaction and coupling between the temporal. variability of the shelf-slope front and the spatial heterogeneity of fish larval populations in a small area of the NW Mediterranean during spring. More specificically, our aim was to ascertain if the progressive inshore-offshore spread of fish larvae is constricted by the highly fluctuating spatial location of the front. For this purpose, 3 oceanographic cruises were carried out over a short time interval (every $10 \mathrm{~d}$ ).

\section{MATERIALS AND METHODS}

The study area was located off the northern Catalan coast (NW Mediterranean) (Fig. 1). Stations were located ca every $8.5 \mathrm{~km}$, from close inshore to beyond the location of the shelf-slope front. Extensive sampling surveys were carried out in May and June 1992 13 to 21 May (Prim 1 Survey), 2 to 9 June (Prim 2 Survey), and 18 to 25 June (Prim 3 Survey). With the exception of a few stations that could not be re-sampled due to logistic problems, the same stations were sampled in each of the 3 surveys.
Samples were collected using a bongo design with $60 \mathrm{~cm}$ diameter nets with $300 \mu \mathrm{m}$ mesh. The volume of water filtered was estimated using a flowmeter mounted centrally in the mouth of one of the nets. Oblique hauls were made both day and night either integrating the entire water column or, if bottom depth was greater than $200 \mathrm{~m}$, from $200 \mathrm{~m}$ to the surface. Counts of fish larvae, from one of the nets, were standardized to numbers per $10 \mathrm{~m}^{2}$ of sea surface.

Vertical profiles of temperature and salinity, from near the bottom to the surface, were obtained using a Neil Brown CTD (conductivity, temperature, depth) profiler. The hydrographic measurements were taken at each station plus an additional transect located at the northernmost part of the study area.

Although the sampling was performed over a short period of time, both species composition and relative abundance changed markedly during this period. Accordingly, comparisons among the the 3 cruises were addressed through analysis of multispecies patterns instead of straight comparison of individual taxa. The classification of multispecies larval data sets into sample groups is a widely applied technique for this kind of data (Moser et al. 1993). The approach of Field et al. (1982) was employed in an effort to elucidate the main physical features responsible for the horizontal distribution patterns for fish larvae in the study area: patterns among the larvae were first established, and an endeavour to interpret them in terms of the environmental. data was then made. Only taxa present at at least $10 \%$ of the stations were included in the analysis. A square-root transformation was performed on the larval abundance data, and the Bray-Curtis measure of similarity was applied. Station classifications were established by applying UPGMA to the Bray-Curtis matrix (Sneath \& Sokal 1973). Finally, the station groupings produced by the analyses were mapped.

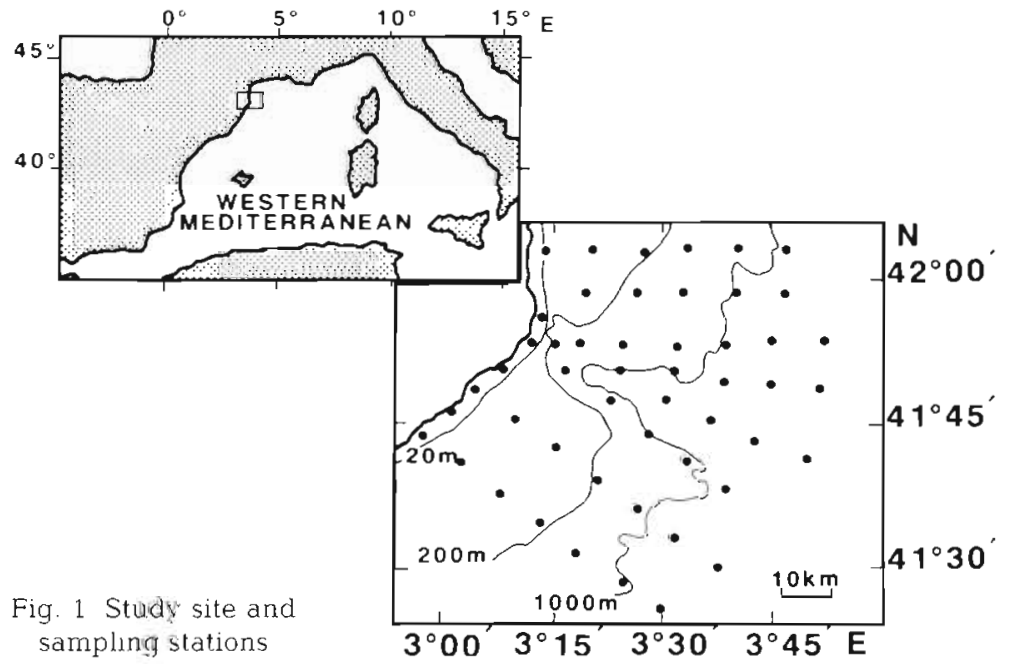

\section{HYDROGRAPHIC CONDITIONS}

The physical structures detected during the 3 cruises have been described by Alvarez et al. (in press). Summarizing their findings: High spatial and temporal variability in salinity and density gradients by the influx of continental runoff occurred from mid-May to the end of June 1992. Both the position and the structure of the shelf-slope salinity front were affected by that variability.

On the Prim 1 survey (mid-May), the shelf-slope front was located a considerable distance $(50 \mathrm{~km})$ offshore, and there 

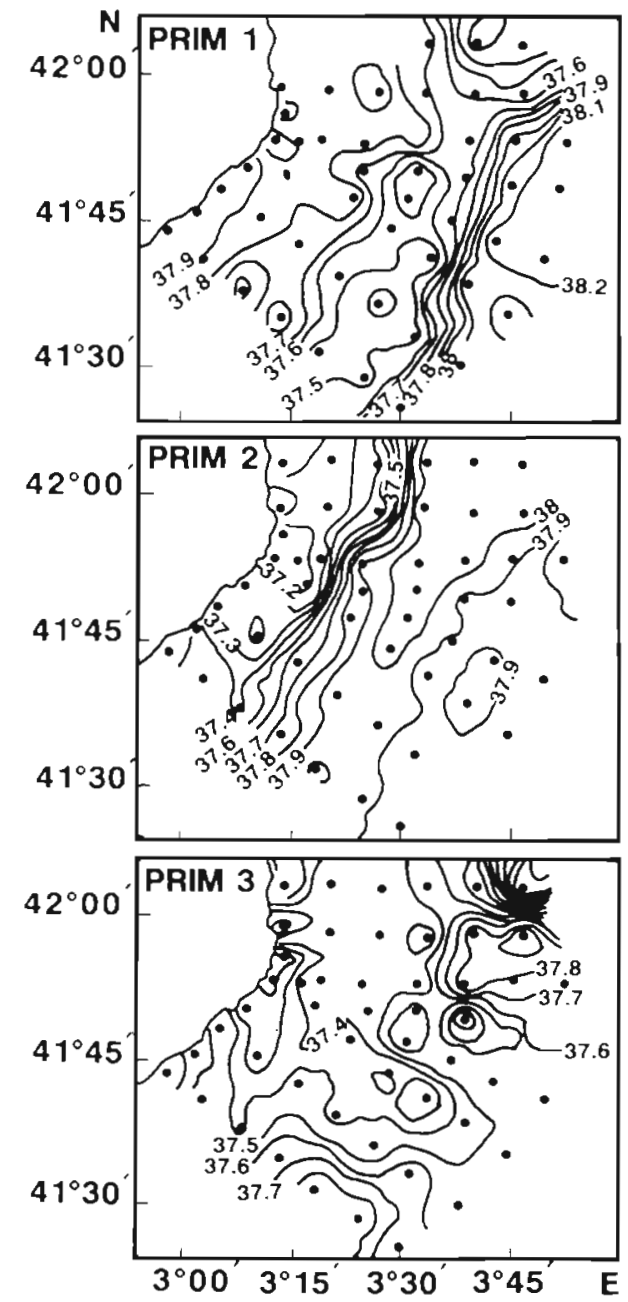

Fig. 2. Surface $(10 \mathrm{~m})$ salinity distributions for the 3 surveys (Prim 1, Prim 2 and Prim 3). (•) CTD stations

was a tongue of water of relatively low salinity, less than $37.5 \%$ at the surface $(10 \mathrm{~m})$, between the shelf and the open sea (Fig. 2). The pattern at $25 \mathrm{~m}$ depth was similar. The presence of this fresher water intensified the salinity and density gradients found in the region of the slope. On the Prim 2 survey (early June). a strong salinity gradient was detected much closer inshore, over the shelf (22 km offshore). The continental waters were located near the coast in the upper $25 \mathrm{~m}$ of the water column and were less saline than on the previous survey (values of around $37.3 \%$ at $10 \mathrm{~m}$ ), giving rise to a strong salinity and density front over the shelf. On the Prim 3 survey (late June), the situation had changed considerably. Relatively fresh water ( $<37.5 \%$ at $10 \mathrm{~m}$ ) covered the upper $25 \mathrm{~m}$ over practicully tho entire area. There were large storms during this period, and river discharge was considerable. No frontal structure was observed parallel to the coast in the upper layers of the water column, unlike the 2 pre- vious surveys. At $50 \mathrm{~m}$ depth the frontal signature was evident over the slope (40 km offshore).

\section{RESULTS}

Significant spatial variability in the structure of ichthyoplankton populations was associated with the short-time-scale variability in physical structure occurring between surveys. Tables 1 to 3 list larval abundance by species for each cruise.

On the Prim 1 survey, during which the shelf-slope front was located on the slope, highest numbers of individuals and species were recorded on the shelf and shelf-slope (Figs. 3a, b, Table 1). Classification of samples in to groups established 3 consistent groups of stations: (A) the most coastal stations; (B) stations on the shelf and shelf-slope; and (C) certain stations

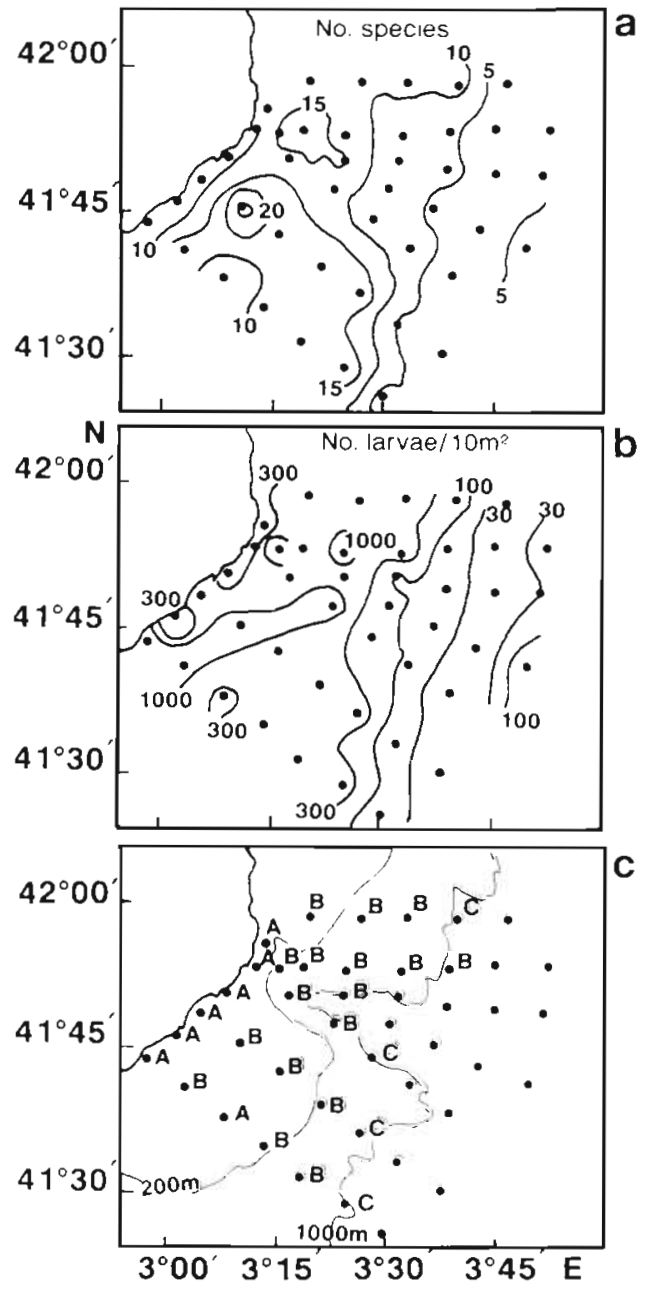

Fig. 3. Prim 1 survey: (a) Larvai abundance (no. per 10 11') (b) number of species recorded at plankton stations ( $)$; and (c) geographic location of groups of stations as established by cluster analysis 
Table 1. Prim 1 survey: mean abundance (no per $1.0 \mathrm{~m}^{2}$ ) (Mean), standard deviation (SD), and frequency of occurrence (\%) of the most common species by groups of stations (A, B, C, offshore) as established by cluster analysis applying the Bray-Curtis index of similarity among 29 taxa using data from 44 stations

\begin{tabular}{|c|c|c|c|c|c|c|c|c|c|c|c|c|}
\hline & \multicolumn{3}{|c|}{ A } & \multicolumn{3}{|c|}{ B } & \multicolumn{3}{|c|}{$\mathrm{C}$} & \multicolumn{3}{|c|}{ Offshore stations } \\
\hline & Mean & $\mathrm{SD}$ & $\%$ & Mean & $\mathrm{SD}$ & $\%$ & Mean & $\mathrm{SD}$ & $\%$ & Mean & $\mathrm{SD}$ & $\%$ \\
\hline Sardina pilchardus & 6.1 & 4.7 & 71.4 & 4.8 & 12.9 & 31.3 & 1.5 & 3.0 & 25.0 & - & - & - \\
\hline Engraulis encrasicolus & - & - & - & 0.4 & 1.5 & 6.3 & 23.8 & 29.0 & 75.0 & 1.4 & 3.2 & 17.6 \\
\hline Maurolicus muelleri & - & - & - & 17.6 & 17.3 & 81.3 & 27.3 & 25.1 & 75.0 & 0.4 & 1.7 & 5.9 \\
\hline Argyropelecus hemigymnus & - & - & - & 1.8 & 4.2 & 18.8 & 15.5 & 14.6 & 75.0 & 9.8 & 9.3 & 64.7 \\
\hline Paralepididae & - & - & - & 1.6 & 6.3 & 6.3 & 17.8 & 22.1 & 75.0 & 2.8 & 4.9 & 29.4 \\
\hline Myctophum punctatum & 1.6 & 4.2 & 14.3 & 10.5 & 9.3 & 75.0 & 33.0 & 38.8 & 75.0 & 3.2 & 10.0 & 17.6 \\
\hline Ceratoscopelus maderensis & 0.9 & 2.3 & 14.3 & 10.8 & 14.2 & 68.8 & 17.8 & 9.6 & 100.0 & 1.5 & 4.3 & 11.8 \\
\hline Lampanyctus crocodilus & 2.6 & 3.3 & 42.9 & 9.8 & 14.2 & 62.5 & 51.3 & 29.8 & 100.0 & 8.9 & 27.6 & 29.4 \\
\hline Serranus hepatus & - & - & - & 2.5 & 4.7 & 25.0 & - & - & - & - & - & - \\
\hline Trachurus trachurus & 1.3 & 2.2 & 28.6 & 25.8 & 17.2 & 100.0 & 4.3 & 4.9 & 50.0 & 1.6 & 6.5 & 5.9 \\
\hline Boops boops & 94.6 & 83.5 & 100.0 & 92.0 & 1.41 .9 & 87.5 & 18.5 & 17.0 & 75.0 & 4.5 & 4.0 & 58.8 \\
\hline Diplodus sargus & 174.4 & 348.0 & 100.0 & 17.1 & 40.8 & 56.3 & 4.0 & 4.7 & 50.0 & 2.8 & 9.3 & 11.8 \\
\hline Cepola macrophtalma & 1.0 & 2.6 & 28.6 & 3.8 & 8.0 & 31.3 & 1.8 & 3.5 & 25.0 & - & - & - \\
\hline Labridae & 7.4 & 8.2 & 57.1 & 0.6 & 2.3 & 6.3 & - & - & - & - & - & - \\
\hline Blenniidae & 4.7 & 4.1 & 71.4 & 2.3 & 5.1 & 18.8 & - & - & - & - & - & - \\
\hline Callionymus spp. & 19.9 & 19.8 & 100.0 & 319.9 & 244.9 & 100.0 & 13.0 & 17.0 & 75.0 & 1.7 & 3.8 & 17.6 \\
\hline Gobiidae & 24.0 & 31.9 & 71.4 & 97.7 & 72.7 & 90.0 & 6.0 & 4.1 & 75.0 & 1.5 & 4.3 & 11.8 \\
\hline Arnoglossus sp. & 15.6 & 12.7 & 85.7 & 222.5 & 214.4 & 100.0 & 12.8 & 6.7 & 100.0 & 5.1 & 9.5 & 35.5 \\
\hline Buglossidium luteum & 1.6 & 2.7 & 28.6 & 11.6 & 15.2 & 62.5 & - & - & - & - & - & - \\
\hline
\end{tabular}
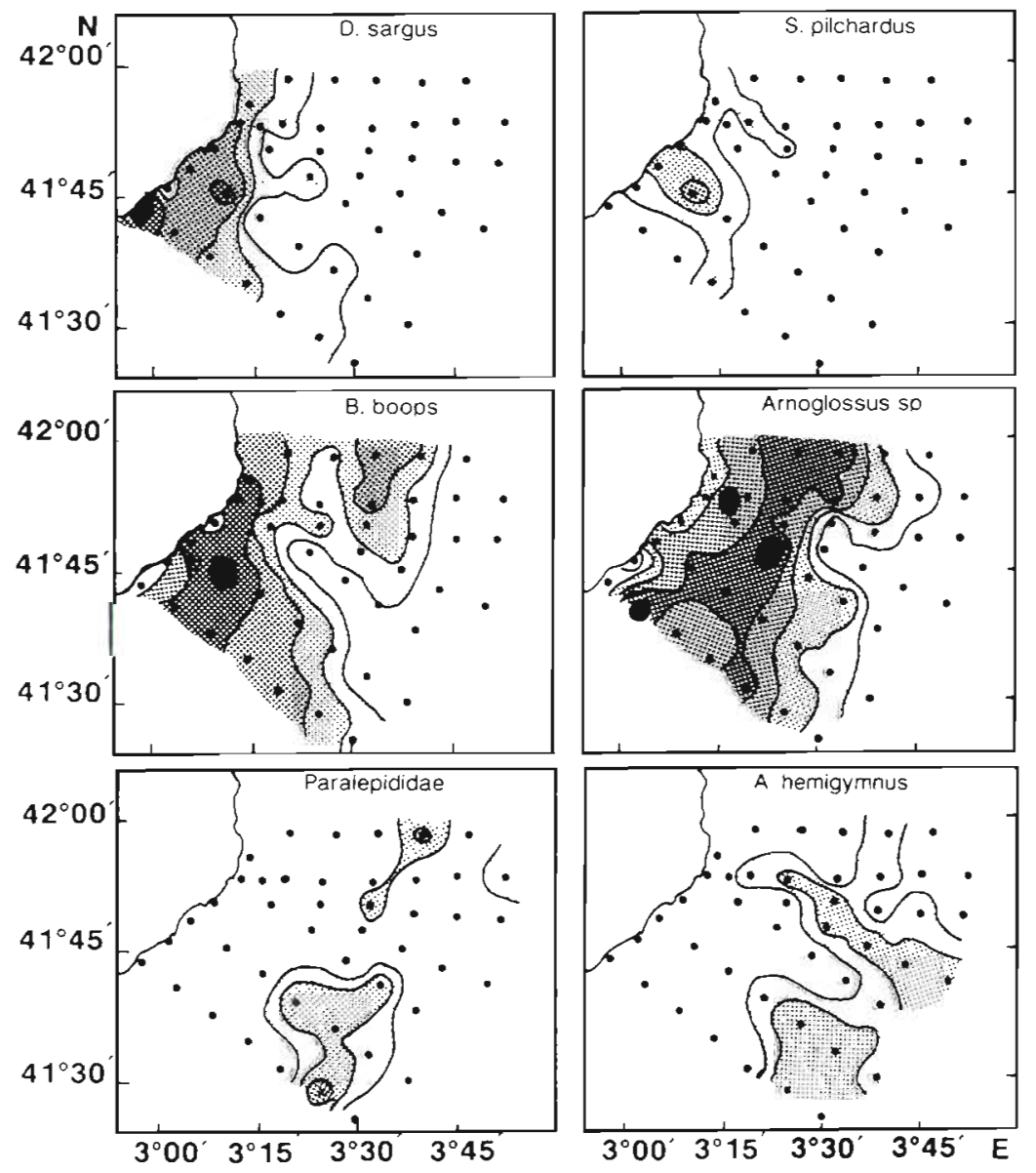

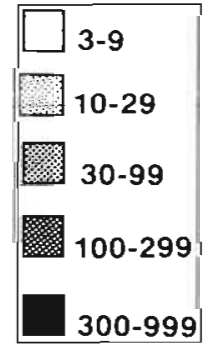

Fig. 4. Prim 1 survey: spatial distributions (no. per $10 \mathrm{~m}^{2}$ ) 6 species representing different distribution patterns 


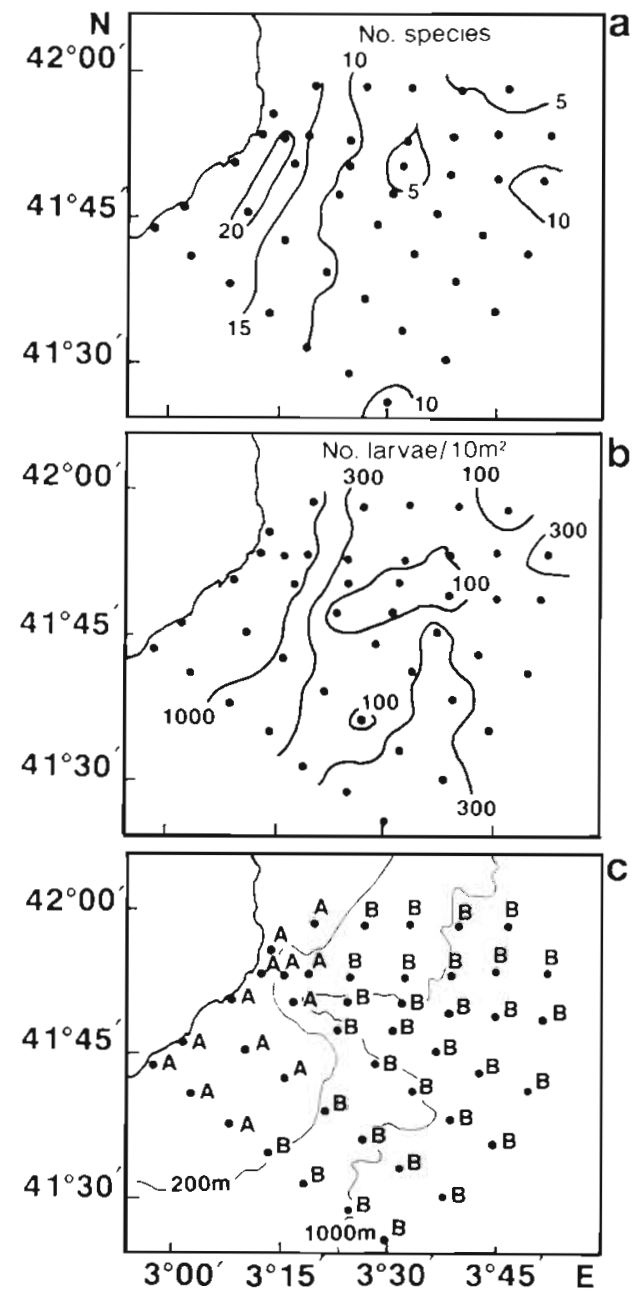

Fig. 5. Prim 2 survey: (a) larval abundance (no. per $10 \mathrm{~m}^{2}$ ): (b) number of species recorded at plankton stations ( $)$; and (c) geographic location of groups of stations as established by cluster analysis

located over the $1000 \mathrm{~m}$ isobath (Fig. 3c). The remaining stations, i.e. beyond the $1000 \mathrm{~m}$ isobath (offshore stations), were very dissimilar and did not form a cohesive group. The most abundant species at the coastal stations (Group A) was Diplodus sargus; other species were Sardina pilchardus and species of the Families Blenniidae and Labridae. Species making up the shelf and shelf-slope cluster (Group B) were those with shelf-dwelling adults, e.g. Arnoglossus spp., Buglossidium luteum, Callionymus spp., Gobiidae, Trachurus trachurus and some coastal species (such as Boops boops) (Fig. 4). Although larvae of mesopelagic species, e.g. Ceratoscopelus maderensis, Lampanyctus crocodilus, Maurolicus muelleri, Myctophum punctatum and Paralepididae, were also present in this group of stations, these were mainly associated with the third group of stations (Group C) along the
$1000 \mathrm{~m}$ isobath. Larval fish abundance and number of species at the rest of the stations (offshore stations) were low; the mesopelagic fish Argyropelecus hemigymnus was the most abundant species (Fig. 4, Table 1).

On the Prim 2 survey the frontal structure ran nearly parallel to the coast and was located on the shelf. Highest numbers of individuals and species were recorded between the coastline and the frontal position (Fig. 5a, b). Cluster analysis resulted in discrimination of 2 large, distinct groups of stations, those on the coastal side of the front (Group A), including the coastal stations and most of the shelf stations, and those on the oceanic side of the front (Group B) (Fig. 5c). Fish in Group A (e.g. Arnoglossus spp., Boops boops, Callionymus spp., Diplodus sargus, Gobiidae) were confined much closer inshore than on the preceding cruise (Fig. 6, Table 2), and their offshore distributions were clearly bounded by the salinity front. Fish collected in the second group belonged to mesopelagic species, e.g. Argyropelecus hemigymnus, Maurolicus muelleri, Myctophum punctatum, Vinciguerria spp. (Fig. 6,

Table 2. Prim 2 survey: mean abundance (no. per $10 \mathrm{~m}^{2}$ ) (Mean), standard deviation (SD), and frequency of occurrence $(\%)$ of the most common species by groups of stations (A, B) as established by cluster analysis applying the Bray-Curtıs index of similarity among 31 taxa using data from 44 stations

\begin{tabular}{|c|c|c|c|c|c|c|}
\hline & \multicolumn{3}{|c|}{$\mathrm{A}$} & \multicolumn{3}{|c|}{$B$} \\
\hline & Mean & $\mathrm{SD}$ & $\%$ & Mean & $\mathrm{SD}$ & $\%$ \\
\hline $\begin{array}{l}\text { Engraulis } \\
\text { encrasicolus }\end{array}$ & 242.05 & 322.1 & 100.0 & 44.1 & 98.8 & 64.5 \\
\hline $\begin{array}{l}\text { Argyropelecus } \\
\text { hemigymnus }\end{array}$ & - & - & - & 33.7 & 30.9 & 80.6 \\
\hline $\begin{array}{l}\text { Maurolicus } \\
\text { muelleri }\end{array}$ & 2.9 & 5.8 & 23.1 & 17.3 & 17.9 & 77.4 \\
\hline Vinciguerria spp. & - & -- & - & 1.4 .7 & 26.0 & 41.9 \\
\hline Paralepididae & - & - & - & 19.4 & 20.2 & 74.2 \\
\hline $\begin{array}{l}\text { Myctophum } \\
\text { punctatum }\end{array}$ & 7.3 & 14.7 & 46.2 & 32.6 & 34.3 & 87.1 \\
\hline $\begin{array}{l}\text { Ceratoscopelus } \\
\text { maderensis }\end{array}$ & 16.7 & 23.8 & 76.9 & 16.8 & 23.7 & 61.3 \\
\hline $\begin{array}{l}\text { Lampanyctus } \\
\text { crocodilus }\end{array}$ & 4.1 & 6.7 & 30.8 & 35.1 & 27.4 & 90.3 \\
\hline Serranus hepatus & 30.6 & 31.3 & 92.3 & - & - & - \\
\hline Boops boops & 48.5 & 48.3 & 92.3 & 0.7 & 2.2 & 9.7 \\
\hline Diplodus sargus & 57.3 & 63.5 & 84.6 & 0.6 & 3.4 & 3.2 \\
\hline $\begin{array}{l}\text { Cepola } \\
\text { macrophthaima }\end{array}$ & 67.3 & 63.4 & 92.3 & 0.5 & 1.9 & 6.5 \\
\hline Labridae & 2.5 & 3.9 & 30.8 & - & - & - \\
\hline Blenniidae & 18.5 & 34.2 & 46.2 & 0.7 & 2.1 & 9.7 \\
\hline Callionymus spp. & 454.32 & 296.2 & 100.0 & 2.6 & 9.5 & 9.7 \\
\hline Gobiidae & 220.91 & 130.3 & 100.0 & 1.6 & 5.4 & 12.9 \\
\hline 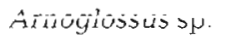 & $22 \hat{9} .92$ & र̂ि1.4 & $\hat{y} \hat{2} . \hat{3}$ & $i . \overline{7}$ & $\hat{\delta} . \mathrm{i}$ & $0 . \overline{5}$ \\
\hline $\begin{array}{l}\text { Buglossidium } \\
\text { luteum }\end{array}$ & 35.5 & 33.4 & 84.6 & - & - & - \\
\hline
\end{tabular}



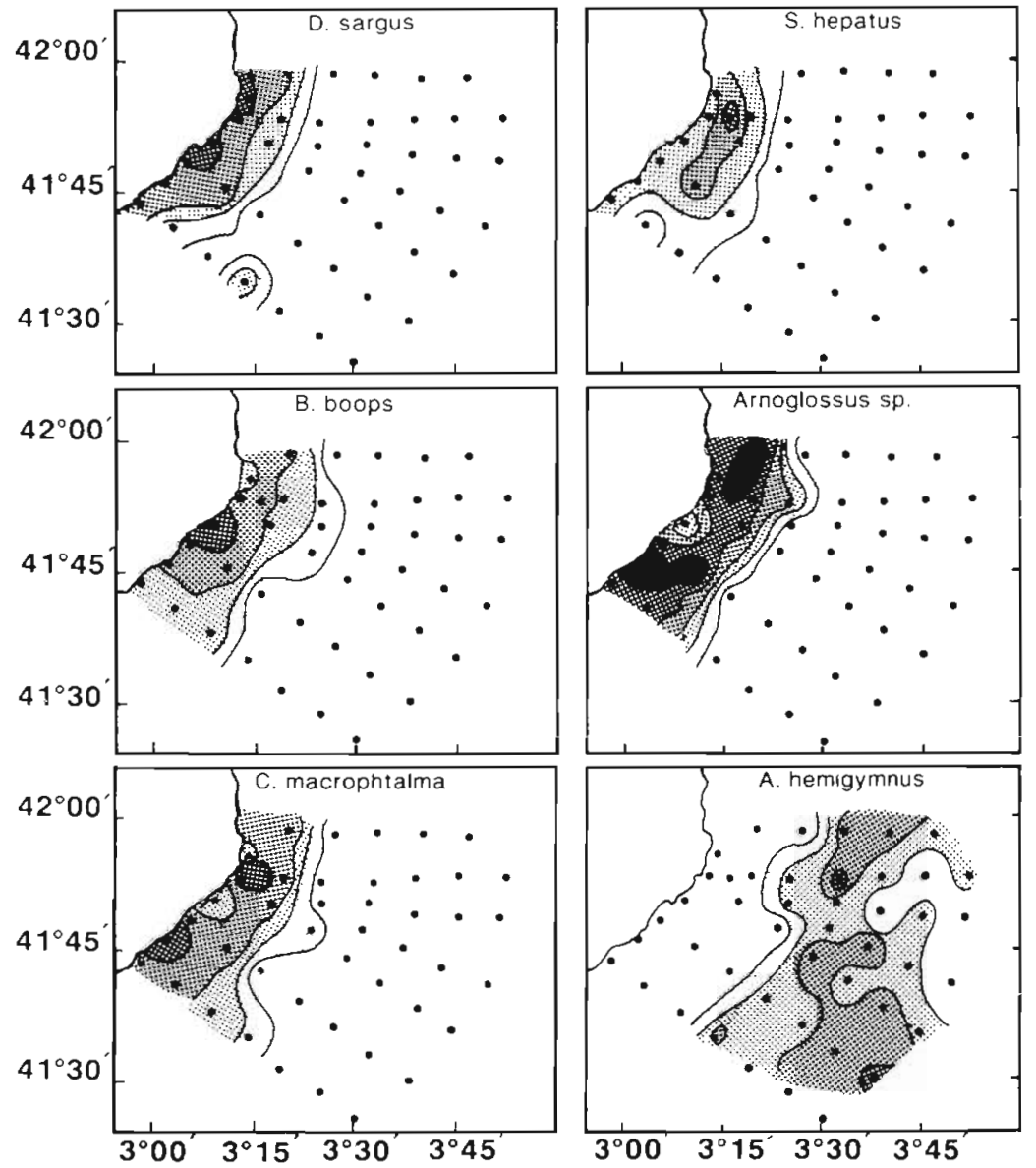

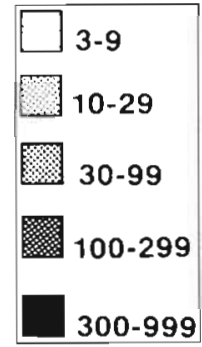

Fig. 6. Prim 2 survey: spatial distributions (no. per $10 \mathrm{~m}^{2}$ ) of 6 species representing different distribution patterns

Table 3. Prim 3 survey: mean abundance (no per $\left.10 \mathrm{~m}^{2}\right)$ (Mean), standard deviation (SD), and frequency of occurrence (\%) of the most common species by groups of stations (A, B, C, D) as established by cluster analysis applying the Bray-Curtis index of similarity among 36 taxa using data from 44 stations

\begin{tabular}{|c|c|c|c|c|c|c|c|c|c|c|c|c|}
\hline & \multicolumn{3}{|c|}{ A } & \multicolumn{3}{|c|}{ B } & \multicolumn{3}{|c|}{ C } & \multicolumn{3}{|c|}{ D } \\
\hline & Mean & $\mathrm{SD}$ & $\%$ & Mean & $\mathrm{SD}$ & $\%$ & Mean & $\mathrm{SD}$ & $\%$ & Mean & SD & $\%$ \\
\hline Engraulis encrasicolus & 1091.0 & 775.2 & 100.0 & 3476.6 & 2696.8 & 100.0 & 1424.0 & 474.8 & 100.0 & 172.2 & 195.2 & 80.0 \\
\hline Argyropelecus hemigymnus & - & - & - & 32.6 & 52.5 & 72.2 & 38.9 & 21.5 & 100.0 & 36.1 & 20.6 & 100.0 \\
\hline Maurolicus muelleri & 1.0 & 2.6 & 14.3 & 38.2 & 28.4 & 88.9 & 37.4 & 30.5 & 100.0 & 10.5 & 13.5 & 60.0 \\
\hline Vinciguerria sp. & - & - & - & 3.5 & 6.5 & 33.3 & 28.6 & 48.7 & 62.5 & 59.6 & 58.1 & 80.0 \\
\hline Paralepididae & - & - & - & 7.6 & 9.6 & 56.0 & 46.5 & 66.2 & 75.0 & 41.8 & 41.1 & 90.0 \\
\hline Myctophum punctatum & 1.1 & 3.0 & 14.3 & 56.2 & 37.5 & 100.0 & 77.3 & 69.8 & 100.0 & 62.1 & 42.3 & 100.0 \\
\hline Lampanyctus crocodilus & 7.0 & 6.9 & 71.4 & 28.6 & 21.1 & 88.9 & 57.6 & 38.4 & 100.0 & 101.5 & 52.6 & 100.0 \\
\hline Ceratoscopelus maderensis & 19.1 & 17.5 & 85.7 & 82.3 & 111.9 & 94.4 & 16.5 & 10.9 & 100.0 & 41.9 & 56.3 & 50.0 \\
\hline Serranus hepatus & 7.1 & 7.4 & 71.4 & 23.7 & 16.9 & 88.9 & 2.1 & 3.9 & 25.0 & - & - & - \\
\hline Trachurus trachurus & - & - & - & 7.9 & 11.4 & 50.0 & 4.1 & 6.6 & 37.5 & - & - & - \\
\hline Trachurus mediterraneus & 12.1 & 19.7 & 57.1 & 3.9 & 5.5 & 38.9 & 21.5 & 22.2 & 75.0 & - & - & - \\
\hline Boops boops & 3.6 & 3.5 & 57.1 & 3.1 & 5.1 & 33.3 & - & - & - & - & - & - \\
\hline Cepola macrophthalma & 7.1 & 5.0 & 85.7 & 85.5 & 64.4 & 100.0 & 9.9 & 16.2 & 37.5 & - & - & - \\
\hline Blenniidae & 7.6 & 11.9 & 56.0 & 5.1 & 6.4 & 44.8 & 2.8 & 4.0 & 37.5 & - & - & - \\
\hline Callionymus spp. & 7.7 & 8.0 & 70.0 & 132.8 & 91.0 & 100.0 & 10.8 & 12.3 & 75.0 & - & - & - \\
\hline Gobiidae & 28.3 & 13.5 & 100.0 & 76.5 & 61.1 & 94.4 & 17.5 & 17.3 & 75.0 & - & - & - \\
\hline Scomber japonicus & 11.0 & 10.6 & 85.7 & 10.2 & 17.4 & 44.4 & 18.4 & 25.7 & 75.0 & - & - & - \\
\hline Arnoglossus sp. & 8.3 & 8.8 & 71.4 & 94.2 & 88.1 & 100.0 & 7.8 & 7.4 & 62.5 & 4.9 & 8.3 & 30.0 \\
\hline
\end{tabular}


Table 2). There was a clear separation between the 2 groups of stations.

On the Prim 3 survey continental runoff covered nearly the entire study area, and rainfall and storms at sea were the predominant meteorological features. No frontal structure was found parallel to the coast at the surface, unlike the 2 previous surveys. However it was evident at deeper layers $(50 \mathrm{~m})$ and was located over the slope. Larval abundance and number of species were highest over a broad central strip (Fig. 7a, b). The 4 most cohesive groups of stations established by cluster analysis were: (A) stations close to the coast, (B) stations in the central band across the study area, whose offshore extent was bounded by the position of the front, and (C and D) 2 groups of stations on the oceanic front. Stations in Group C were near the $1000 \mathrm{~m}$ isobath; and stations in Group D were the most oceanic (Fig. 7c). The coastal stations were characterized by a low number of species and larvae of the Families Labridae and Blenniidae. The shelf and slope stations (Group B) were composed of larve whose adults were typical shelf-dwelling fish species, such as Arnoglossus spp., Callionymus spp., Cepola macrophthalma, Engraulis encrasicolus, and Serranus hepatus and 1 mesopelagic species Ceratoscopelus maderensis (Fig. 8, Table 3). Stations in Groups C and D were characterized by mesopelagic species (e.g. Argyropelecus hemigymnus, Lampanyctus crocodilus, Mauroljcus muelleri, Myctophum punctatum), with the difference between the two being that the coastal and shelf species present in stations of Group C were virtually absent from the stations in Group D (Table 3).

Distributions of shelf-dwelling species were broader than they had been on the preceding survey $10 \mathrm{~d}$ earlier, and there was a zone of overlap between shelfdwelling and mesopelagic species. Both species composition and the contribution of the different species to the total larval fish population on this survey differed markedly from those on the 2 previous cruises.

\section{DISCUSSION}

On the northern Catalan coast, spring is a transition period characterized by strong salinity and density gradients and the development of the seasonal thermocline (Masó \& Tintoré 1990). This is also a transition period in the spawning of fishes (Sabatés \& Masó 1992) during which the composition of the larval fish community is highly variable over short lengths of time. In the present study the most pronounced change in species composition was observed during the last cruise, i.e. the beginning of summer, and coincided with the onset of the spawning period of certain species (e.g Trachurus mediterraneus, Scomber japonicus) and

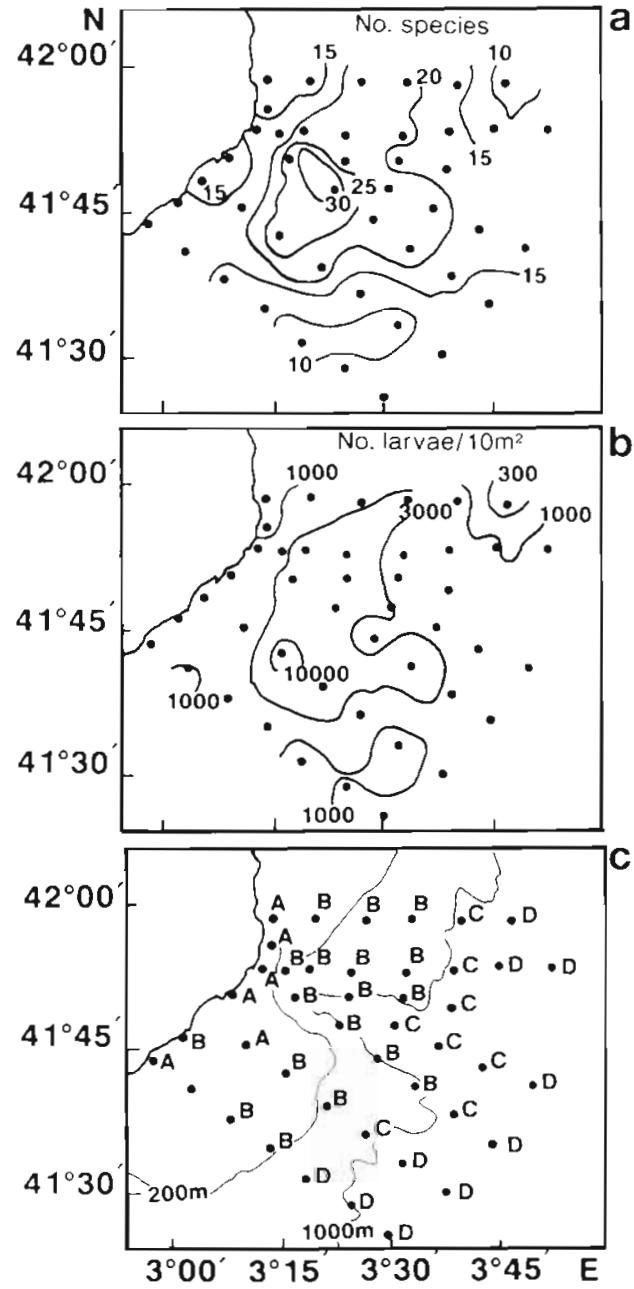

Fig. 7. Prim 3 survey: (a) larval abundance (no. per $10 \mathrm{~m}^{2}$ ); (b) number of species recorded at plankton stations $(\bullet)$; and (c) geographic location of groups of stations as established by cluster analysis

with the maximum spawning intensity for anchovy, Engraulis encrasicolus (Palomera 1992) whose larval concentrations accounted for $72 \%$ Additionally, the larvae of winter-spawning species had declined in number or disappeared (e.g. Sardina pilchardus, Buglossidium luteum, Arnoglossus spp.) by this time.

Water circulation in the Western Mediterranean is characterized by physical mechanisms conducive to high mesoscale variability (García et al. 1994). The system formed by the shelf-slope front and the associated current is subject to high spatio-temporal instability characterized by the frequent appearance of energetic eddies, filaments, and mid-depth intrusions (Wang et al. 1988, La Violette et al. 1990, Tintoré et al. 1990). Variations in physical processes on a spatial scale of just a few kilometers, as in the case of density fronts, have significant biological impact at the population 

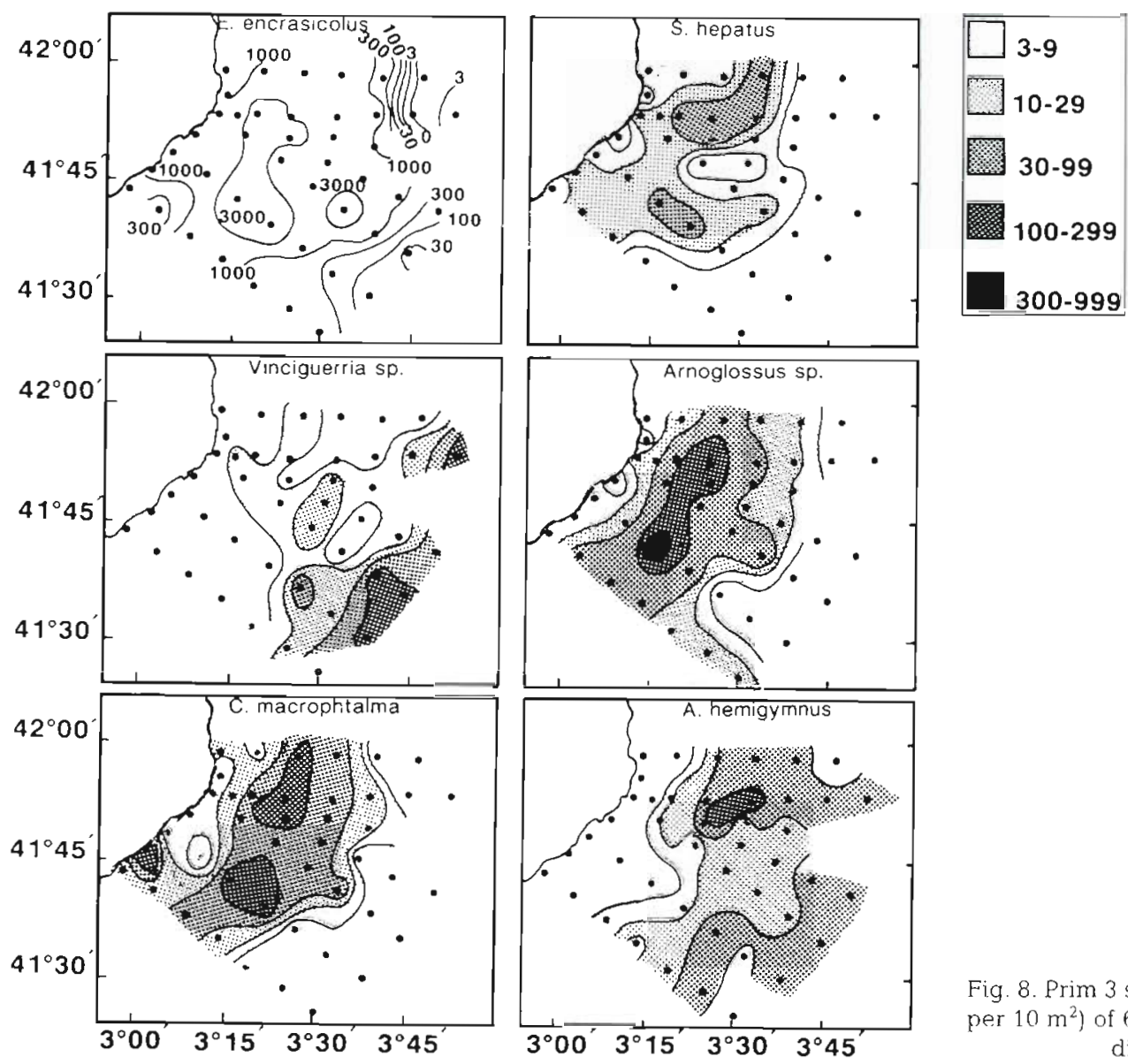

Fig. 8. Prim 3 survey: spatial distributions (no. per $10 \mathrm{~m}^{2}$ ) of 6 species representing different distribution patterns

level (e.g. Daly \& Smith 1993). The changes observed in the position of the shelf-slope front, over a period just exceeding 1 mo during the present study, were associated with important changes in the distribution and abundance of fish larvae.

The influence of the shelf-slope front on the larval fish population was particularly pronounced when the front was located inshore (Prim 2 survey). High values for both larval density and number of species were recorded on the coastal side of the front and were basically attributable to coastal and shelf species. The front appeared to limit the larval distribution of these species to within $22 \mathrm{~km}$ of the coast, possibly by acting as a barrier preventing their offshore displacement. The larvae of mesopelagic species were located on the oceanic side of the front. Analysis of multispecies distribution patterns for the second survey revealed only 2 large groups of stations, one on either side of the front. During the other 2 surveys, when the front was located on the slope (Prim 1 and Prim 3 surveys), high values for larval density and number of species were recorded both on the shelf and shelf-slope. These findings were essentially due to the larvae of shelf species, though the presence of larvae of mesopelagic species in the same area also contributed to high values. The statistical analyses for the Prim 1 and 3 survey identified 4 groups of stations which basically corresponded to the bathymetry. As previously reported (Sabatés 1990a), species may be associated with more than one of these groups, although relative species abundance varies from group to group. The front cannot act as a barrier separating the distributions of adults of shelf and mesopelagic species because water depth in the region enables adults of mesopelagic species to be present on both sides of the front. Thus, on each of the 3 surveys, offshore dispersal of fish larvae of only the shelf-dwelling species was bounded by the geographical position of the front.

The effect of fronts on planktonic organisms, either as convergence zones or barriers, depends upon the nature of the front considered and the behaviour and developmental stage of the organisms concerned (Sournia 1993, 1994). Frontal regions have been identified as areas favouring the concentration of fish larvae because of high biological production associated with such structures (Pingree et al, 1974, Le Fèvre 1986, Kiørboe et al. 1988, Nakata 1989, Sabatés 1990b. Grimes \& Finucane 1991). Other researchers have con- 
sidered fronts to be boundaries (Fortier \& Gagne 1990) or barriers restricting larval dispersal (lles \& Sinclair 1982, Iwatsuki et al. 1989) and contributing to larval survival. It has been shown that fronts are not absolute barriers to organisms which are capable of crossing the fronts, and hence they have regarded the boundaries between different water masses as being dynamic in nature (Govoni 1993, Perry et a1. 1993). In the present study, the most inshore location of the front (during the second cruise) appeared to be a restriction to movement of larvae across the front. On the whole, the front is a hydrodynamic structure that delimits the dispersal area of the larvae of shelf species, and larval concentrations in the frontal zone were not especially high. The apparent disparities in frontal effects reported in the literature are probably related to sampling scale, type of front and the length of time the structure remains in a given location. If the frontal zone is sufficiently long-lived, there is adequate response time for organisms at the different trophic levels to take advantage of the high productivity generated, resulting in accumulation in the frontal zone (Olson \& Backus 1985 , Angel 1989, Olson et al. 1994) Thus, although in our study the spatial scale did not allow us to determine if in fact the larvae are concentrating at the convergence zone of the front, the short time scale of fluctuations in frontal location in spring led us to think that the front may not act as a mechanism for the accumulation of fish larvae at that time of year.

The results of this study indicate a high degree of coupling between the position of the shelf-slope front and the distribution of fish larvae. The limits of the distribution areas fluctuated considerably over a short time scale as a result of high variability in the location of the front.

Acknowledgements. We thank Dr M. Masó for valuable discussions. We are also grateful to all the partıcipants in the Prim surveys for their help in collecting the samples. Thanks are also given to Mrs I. Hinojosa and A. Blanco for sorting the samples. Mr R. Sacks prepared the English version. This work has been supported by CICYT MAR 91-0860.

\section{LITERATURE CITED}

Alvarez A, Tintoré J, Sabatés A (in press) Flow modification and shelf-slope exchange induced by a submarine canyon off the northeast Spanish coast. J Geophys Res

Angel MV (1989) Vertical profiles of pelagic communitıes in the vicinity of the Azores front and their implications to deep ocean ecology. Prog Oceanogr 22:1-46

Daly KL, Smith WO Jr (1993) Physical-biological interactions influencing marine plankton production. A Rev Ecol Syst 24:555-585

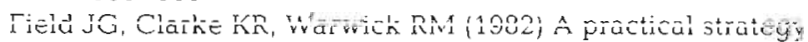
for analysing multispecies distribution patterns. Mar Ecol Prog Ser 8:37-52

Font J, Salat J, Tintoré J (1988) Permanent features in the cir- culation of the Catalan Sea. Oceanol Acta Spec Vol 9:51-57 Fortier L, Gagné JA (1990) Larval herring dispersion, growth and survival in the St. Lawrence estuary: matchmismatch or membership/vagrancy? Can J Fish Aquat Scj 47:1898-1912

Garcia E. Tintoré J, Pinot JM, Font J, Manriquez M (1994) Surface circulation and dynamics of the Balearic Sea. Seasonal and interannual variability of the Western Mediterranean Sea. Coast Estuar Stud 46:73-91

Govoni JJ (1993) Flux of larval fishes across frontal boundares: examples from the Mississippi River plume front and the western Gulf Stream front in winter Bull Mar Sci 53: $538-566$

Govoni JJ, Hoss DE, Colby DR (1989) The spatial distribution of larval tishus about the Mississippi River plume. Limnol Oceanogr 34:178-187

Grimes CB, Finucant: JH (1991) Spatial distribution and abundance of larval and juvenile fish, chlorophyll and macrozooplankton around the Mississippi River discharge plume, and the role of the plume in fish recruitment. Mar Ecol Prog Ser 75:109-119

Iles TD, Sinclair M (1982) Atlantıc herring: stock discreteness and abundance. Science 215:627-633

I watsuki Y, Nakata H, Hirano R (1989) The thermohaline front in relation to tish larvae. Rapp PV Réun Cons Int Explor Mer 191:119-126

Kingsford MJ (1990) Linear oceanographic features: a focus for research on recruitment processes. Aust J Ecol 15: $391-401$

Kiørboe T, Munk P, Richardson PK, Christensen V, Paulsen H (1988) Plankton dynamics and larval herring growth, drift and survival in a frontal area. Mar Ecol Prog Ser 44: $205-219$

La Violette PE, Tintoré J, Font J (1990) The surface circulation of the Balearic Sea. J Geophys Res 95:1559-1568

Le Fèvre J (1986) Aspects of the biology of frontal systems. Adv Mar Biol 23:163-299

Legendre L, Demers S (1984) Towards dynamic biological oceanography and limnology. Can J Fish Aquat Sci 41:2-19

Mackas DL, Denman KL, Abbot MR (1985) Plankton patchiness: biology in the physical vernacular Bull Mar Sci 37: $652-674$

Masó M. Tintore J (1991) Variability of the shelf water off the northeast Spanish coast. J Mar Syst 1:441-450

Moser HG, Smith PE, Fuiman LA (1993) Advances in the early life history of fishes. Part 1. Larval fish assemblages and ocean boundaries. Bull Mar Scj 53:283-722

Nakata $H$ (1989) Transport and distribution of fish eggs and larvae in the vicinity of coastal fronts. Rapp PV Réun Cons Int Explor Mer 191:153-159

Olson DB, Backus RH (1985) The concentrating of organisms at fronts: a cold water fish and a warm-core ring. J Mar Res 43:113-137

Olson DB, Hitchcock GL, Mariano A, Ashjian CJ, Peng G, Nero RW, Podesta GP (1994). Life on the edge: marine life and fronts. Oceanography 7:52-60

Palomera 1 (1992) Spawning of anchovy Engraulis encrasicolus in the Northwestern Mediterranean relative to hydrographic features in the region. Mar Ecol Prog Ser 79: 215-233

Pingree RD, Foster GR, Morrison GK (1974) Turbulent convergent tidal fronts. J Mar Biol Ass UK 56:469-479

Perry Rl, Harding GC, Loder JW, Tremblay MJ, Sinclair MM, Dininviter KF (1003). Zooplentrton divtributions at the Georges Bank frontal system: retention or dispersion? Cont Shelf Res 13:357-383

Sabatés A (1990a) Distribution pattern of larval fish popula- 
tions in the Northwestern Mediterranean. Mar Ecol Prog Ser 59:75-82

Sabatés A (1990b) Changes in the heterogeneity of mesoscale distribution patterns of larval fish associated with a shallow coastal haline front. Estuar Coast Shelf Sci 30 131-140

Sabatés A, Masó M (1992) Unusual larval fish distribution pattern in a coastal zone of the western Mediterranean Limnol Oceanogr 37:1252 1260

Sneath PHA, Sokal RR (1973) Numerical taxonomy. WH Freeman and Company, San Francisco

This article was submitted to the editor
Sournia A (1993) Frontal studies in France-JGOFS: a fouryear summary. Ann Inst Oceanogr 69:47-55

Sournia A (1994) Pelagic blogeography and fronts. Prog Oceanogr 34:109-120

Tintoré J, Wang DP, La Violette PE (1990) Eddies and thermohaline intrusions on the shelf/slope front off the NE Spain coast. J Geophys Res 95:1627-1633

Wang DP, Vieira M. Salat J, Tintoré J, La Violette PE (1988) A shelf-slope front filament off Northeast Spanish coast. J Mar Res 46:321-332

Manuscript first received: May 26, 1995

Revised version accepted: December 11, 1995 